\title{
Plant community tolerant to trace elements growing on the degraded soils of São Domingos mine in the south east of Portugal: environmental implications
}

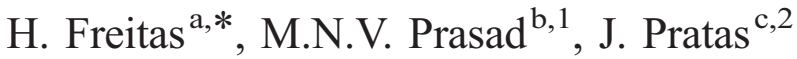 \\ ${ }^{a}$ Departamento de Botânica, Faculdade de Ciências e Tecnologia da Universidade de Coimbra, 3000 Coimbra, Portugal \\ ${ }^{\mathrm{b}}$ Department of Plant Sciences, University of Hyderabad, Hyderabad 500046, A.P. India \\ ${ }^{\mathrm{c}}$ Departamento de Ciências da Terra, Faculdade de Ciências e Tecnologia da Universidade de Coimbra, 3000 Coimbra, Portugal
}

Received 10 February 2003; accepted 14 May 2003

\begin{abstract}
The selection of trace element tolerant species is a key factor to the success of remediation of degraded mine soils. Mining activities generate a large amount of waste rocks and tailings, which get deposited at the surface. The degraded soils, the waste rocks and tailings are often very unstable and will become sources of pollution. The direct effects will be the loss of cultivated land, forest or grazing land, and the overall loss of production. The indirect effects will include air and water pollution and siltation of rivers. These will eventually lead to the loss of biodiversity, amenity and economic wealth. Restoration of a vegetation cover can fulfil the objectives of stabilization, pollution control, visual improvement and removal of threats to human beings. Thus, remediation of mine spoils/tailings and biogeochemical prospecting would rely on the appropriate selection of plant species.

Plant community responds differently on their ability to uptake or exclude a variety of metals. In this work, plant species were sampled from all populations established in an abandoned copper mine of São Domingos, SE Portugal. Plants belonging to 24 species, 16 genera and 13 families were collected from the degraded copper mine of São Domingos. Plant samples were analysed for total $\mathrm{Ag}, \mathrm{As}, \mathrm{Cu}, \mathrm{Ni}, \mathrm{Pb}$, and $\mathrm{Zn}$. The highest concentrations of metals in soils dry matter were $11217.5 \mathrm{mg} \mathrm{Pb} \mathrm{kg}^{-1}, 1829 \mathrm{mg} \mathrm{Cu} \mathrm{kg}^{-1}, 1291 \mathrm{mg} \mathrm{As} \mathrm{kg}-1,713.7 \mathrm{mg} \mathrm{Zn}$ $\mathrm{kg}^{-1}, 84.6 \mathrm{mg} \mathrm{Cr} \mathrm{kg}^{-1}, 54.3 \mathrm{mg} \mathrm{Co} \mathrm{kg}{ }^{-1}, 52.9 \mathrm{mg} \mathrm{Ni} \mathrm{kg}^{-1}$ and $16.6 \mathrm{mg} \mathrm{Ag} \mathrm{kg}^{-1}$. With respect to plants, the higher concentrations of Pb and As were recorded in the semi-aquatic species Juncus conglomeratus with 84.8 and $23.5 \mathrm{mg} \mathrm{kg}^{-1}$ dry weight (DW), Juncus efusus with 22.4 and $8.5 \mathrm{mg} \mathrm{kg}^{-1} \mathrm{DW}$, and Scirpus holoschoenus with 51.7 and $8.0 \mathrm{mg} \mathrm{kg}^{-1} \mathrm{DW}$, respectively. Thymus mastichina also showed high content of As in the aboveground parts, $13.6 \mathrm{mg} \mathrm{kg}^{-1} \mathrm{DW}$. Overall, the results indicate accumulation of various metals by different plant species, with some of these metals being partitioned to the shoots. Environmental implications of these observations are discussed.
\end{abstract}

(C) 2003 Elsevier Ltd. All rights reserved.

Keywords: Trace metals; Metal-tolerant plant community; Copper mine; Portugal

\section{Introduction}

The global budget of toxic trace elements has increased dramatically due to a variety of activities since the dawn industrial revolution (Nriagu, 1979). One of the main sources of trace metal pollution is the mining and smelting of metalliferous ores. Long-term persistence of trace ele-

\footnotetext{
* Corresponding author. Tel.: +351-239-822897; fax: +351-239820780.

E-mail address: hfreitas@ci.uc.pt (H. Freitas).

${ }^{1}$ Tel.: +91-40-23011604; fax: +91-40-23010120/23010145.

${ }^{2}$ Tel.: +351-239860500; fax: +351-239860501.
}

ments in the environment is of human health concern (Shaw, 1990; Hadjiliads, 1997). Mining activities generate a large amount of waste rocks and tailings which get deposited at the surface. The degraded soils, and the waste rocks and tailings are often very unstable and will become sources of pollution. The direct effects will be loss of cultivated land, forest or grazing land, and the overall loss of production (Wong, 2003). The indirect effects will include air and water pollution and siltation of rivers. These will eventually lead to the loss of biodiversity, amenity and economic wealth (Bradshaw, 1993). Restoration of a vegetation cover can fulfil the objectives of stabilization, pollution control, visual improvement and removal of threats to 
human beings. The constraints related to plant establishment, and amendment of the physical and chemical properties of the toxic metal-mined soils, and the choice of appropriate plant species are discussed.

Traditional remedies of soil amelioration are very costly and can only affect the upper layers of the soil. Populations of a variety of higher plant species are known to colonize degraded mine soils in which other cultivated plants can not survive. Thus, the plant community tolerant to trace elements plays a major role in remediation of degraded mine soils (Banuelos and Ajwa, 1999). Plants tolerant to toxic levels of trace elements respond by exclusion, indication or accumulation of metals (Baker, 1981). A number of plant species endemic to metalliferous soils have been found to accumulate metals at extraordinarily high levels $(>1 \%$ and up to $10 \%)$ in contrast to normal concentrations in plants. So far, approximately 400 metal hyperaccumulators have been identified (Baker, 1995). The term hyperaccumulator was first used by Brooks et al. (1977) in relation to plants containing more than $1000-10,000 \mathrm{mg} \mathrm{kg}^{-1}(0.1-1 \%)$ of $\mathrm{Ni}$ in dry tissue. It was not until the early 1980 s that it was realised that hyperaccumulators might be used to remediate polluted soils by growing a crop of one of these plants and harvesting it to remove the pollutants (Chaney, 1983). The success of any phytoremediation technique depends upon the identification of suitable plant species that hyperaccumulate trace metals and produce large amount of biomass using established crop production and management practices (Baker et al., 1991; Brooks, 1983, 1998). The development of hyperaccumulator plants represents a potential for remediation of soils polluted by trace metals (Baker et al., 1994). McGrath et al. (1993) reported the results of field trials in which several hyperaccumulators were grown in polluted soils to reduce the soil content of $\mathrm{Zn}$ from 440 to $300 \mu \mathrm{g} \mathrm{g}^{-1}$, the threshold established by the European Community (Commission of the European Communities, 1986).

The aforementioned works suggested that collecting plant species on contaminated soils may be effective for selecting potential plants to be used in mine remediation. The present work was undertaken to acquire exhaustive information about the ability of plant species growing wild in this polluted area to accumulate $\mathrm{Ag}, \mathrm{As}, \mathrm{Cu}, \mathrm{Ni}, \mathrm{Pb}, \mathrm{Cr}$ and $\mathrm{Zn}$ in order to identify metal-tolerant species. Plant species found in metal polluted/contaminated soils are expected to take up metals and eventually accumulate them (Baker, 1981; Ross, 1994). Plants also developed mechanisms to avoid the uptake of trace elements or exclude them. Therefore, plant community established on mine spoils can be useful to minimize the impacts of mining (Sengupta, 1993). Thus, considering the diversity of plant responses in contaminated sites having different metals and toxicity levels, at various levels, it is important to study the composition of plant community that was established on degraded soils, which would serve as a basic approach for mine remediation. More information about plant community that can grow on metal-contaminated soils is essential to determine their potential for mine reclamation/remediation and for biogeochemical exploration (Kovalevskii, 1979; Fletcher, 1981; Brooks, 1983; Badri and Springuel, 1994; Baker et al., 1994; McInnes et al., 1996).

This study is part of a series of studies that attempt to evaluate the potential for remediation of plant species and communities established in soils contaminated by heavy metal mining and smelting. The site chosen for the study was abandoned in 1966, the mine of São Domingos, in the south-east of Portugal. This is one of the historical mining centres known for its activity since pre-Roman times, with extraction of gold, silver and copper (Gaspar, 1998). The main activity of the mine was copper production. In addition, huge deposits of cupriferous pyrite were also present which have been processed for sulphur production. Remediation of these sites is essential for meeting the environmental regulations and also for human health point of view. Mine leachates into shallow aquifers, runoff to surface water is of human health concern (Sengupta, 1993). Rehabilitation of abandoned mines and mine spoils by phytostabilization, rhizosphere biotechnology and phytoremediation technology is supported by recent literature (Raskin and Ensley, 2000; Wenzel et al., 1999). This work was carried out to get information about the flora of São Domingos mine with special emphasis on metal uptake and accumulation of plant communities established in the contaminated area. Plants and soils were analysed for total $\mathrm{Ag}, \mathrm{As}, \mathrm{Cu}, \mathrm{Ni}, \mathrm{Pb}, \mathrm{Cr}$ and $\mathrm{Zn}$. Patterns of metals accumulation in plants were analysed and implications for phytoremediation are evaluated.

\section{Materials and methods}

\subsection{Site description}

This study was carried out at São Domingos old mine, located in the South of Portugal $\left(37^{\circ} 38^{\prime} 00 \mathrm{~N}\right.$ to $37^{\circ} 40^{\prime} 30 \mathrm{~N}$ and $7^{\circ} 19^{\prime} 05 \mathrm{~W}$ to $\left.7^{\circ} 20^{\prime} 05 \mathrm{~W}\right)$. It is one of the historical mining centres with known activity since pre-Roman times, with extraction of gold, silver and copper. São Domingos belongs to the Iberian pyrite belt, with the outcropping area sequences formed by a unique vertical mass of cupriferous pyrite associated with zinc and lead sulphide. It is similar to many other vulcanogenic massive sulphide mineralizations existing in this belt, from the genetic, morphological and mineralogical point of view. The large area covered by the mine is the result of extraction of more than 25 millions tons of ore (copper concentrate production) from which 9.9 millions tons of cupriferous pyrite (Gaspar, 1998). São Domingos current landscape and historical past makes it one of the most attractive mines in Portugal (Fig. 1).

\subsection{Geochemistry}

The primary mineralization is made of massive sulphides, with more than $85 \%$ of sulphides, essentially pyrite, 


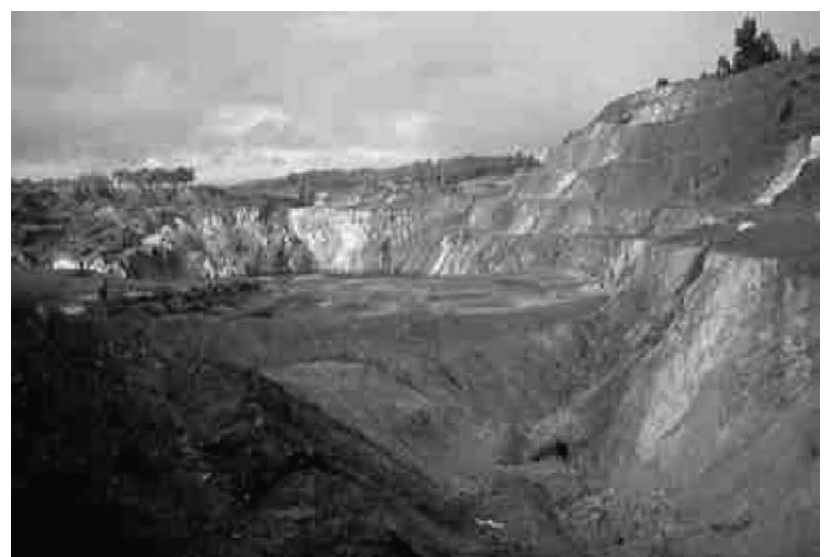

Fig. 1. A recent view of the São Domingos mining landscape.

sphalerite, chalcopyrite, galene and sulphosalts. In the near vicinity of the mine, massive mineralizations of disseminated sulphides with high copper was also present. In São Domingos, the primary mineralization is deeply located. The extensive mineralized deposits were exploited in Roman and pre-Roman times. In the second half of the XIX century, these material got dispersed in a large area of the mine. Initially, only copper was extracted and therefore the ore was burnt openly in several places of the mine. This procedure induced heavy pollution causing damage to extensive areas without vegetation.

São Domingos landscape reveals high degradation with approximately 750000 tons of waste mining material (Fig. 2). The enormous pit, left by extraction works, $122 \mathrm{~m}$ deep, is filled with acid waters $(\mathrm{pH}=1.7)$. The mining effluent is of a serious environmental issue. The acid drainage from the reservoir contaminates soils and groundwater along several $\mathrm{km}$ stretch, affecting ground water and water reservoirs in close vicinity.

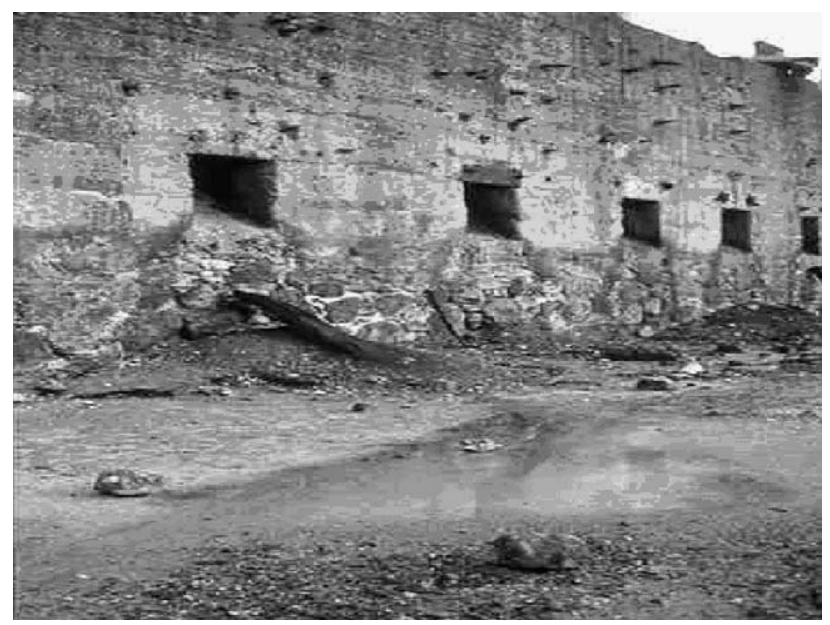

Fig. 2. High degradation and environmental impacts are obvious all along the old mining area.

\subsection{Plant community}

The vegetation is dominated by Quercus ilex and Eucalyptus sp., the most abundant tree. Dominant shrubs are Lavandula stoechas L. subsp. pedunculata (Miller) Samp. and Rozeira and Genista hirsuta Vahl. Plants used in this investigation have been identified with the help of local floras (Franco, 1971; Castroviejo et al., 1986, 1990, 1993, 1997; Talavera et al., 1999).

\subsection{Soil and plant sampling}

Sampling sites were selected after a geobotanical survey. At each site, a variable number of soil samples $(>5)$ at 10-30 $\mathrm{cm}$ in depth were taken for laboratory analysis (Hesse, 1971), and a variable number of plants $(>5)$ of each species was collected. The soils were classified into different categories according to the Soil Survey Staff (1997). Soil samples were then dried at $80{ }^{\circ} \mathrm{C}$ and sieved through a 100 -mesh.

Five plant samples were collected from all species representative of the community of plants found at the in the mining area. Plant samples were cleaned in abundant freshwater and rinsed with distilled water. Dry weights were obtained after oven drying at $60{ }^{\circ} \mathrm{C}$ for 2 days.

\subsection{Chemical analysis}

Soil and plant samples were analysed for total $\mathrm{Ag}$, As, $\mathrm{Co}, \mathrm{Cr}, \mathrm{Cu}, \mathrm{Ni}, \mathrm{Pb}$ and $\mathrm{Zn}$ using atomic absorption spectrophotometer (Perkin-Elmer 2380) and hydride generation (HGS) for As (Lucas and Sequeira, 1971; Aslin, 1976; Vijan et al., 1976; Van Loon, 1985; Pratas, 1996; Kabata-Pendias, 2001). Concentrations of $\mathrm{Cr}$ and $\mathrm{Co}$ were not determined in plants as they were very low. Soil $\mathrm{pH}$ was determined in a soil/water $(1: 2.5)$ suspension with a $\mathrm{pH}-$ meter.

\section{Results and discussion}

Eight metals and $\mathrm{pH}$ were analysed in all soil samples. A summary of this analysis is given in Table 1. High levels of $\mathrm{As}, \mathrm{Cu}, \mathrm{Pb}$ and $\mathrm{Zn}$ were recorded in the soils. Copper concentration in soils could reach $1829.0 \mathrm{mg} \mathrm{kg}^{-1}$ as a

Table 1

Summary of the soil analysis in São Domingos (metals in $\mathrm{mg} \mathrm{kg}^{-1}$ dry weight; S.D. = standard deviation)

\begin{tabular}{lcccr}
\hline & Range & Mean & Median & \multicolumn{1}{c}{ S.D. } \\
\hline $\mathrm{pH}$ & $4.01-6.73$ & 5.06 & 5.14 & 0.64 \\
$\mathrm{Ag}$ & $2.5-16.6$ & 7.5 & 7.0 & 3.6 \\
$\mathrm{As}$ & $37.2-1291.0$ & 392.6 & 353.2 & 323.8 \\
$\mathrm{Co}$ & $20.1-54.3$ & 31.0 & 29.4 & 8.4 \\
$\mathrm{Cr}$ & $5.1-84.6$ & 26.5 & 8.3 & 31.7 \\
$\mathrm{Cu}$ & $87.3-1829.0$ & 553.2 & 443.7 & 442.9 \\
$\mathrm{Ni}$ & $27.2-52.9$ & 42.2 & 43.9 & 6.6 \\
$\mathrm{~Pb}$ & $234.2-12217.5$ & 2693.7 & 2355.1 & 2345.3 \\
$\mathrm{Zn}$ & $103.8-713.7$ & 218.2 & 162.8 & 145.1 \\
\hline
\end{tabular}


result of the former activity of the site (copper smelter). Maximum concentration of As in soils was very high, reaching $1291.0 \mathrm{mg} \mathrm{kg}^{-1}$. The concentration of $\mathrm{Pb}$ in the soil was also very high, $2693.7 \mathrm{mg} \mathrm{kg}^{-1}$ as the average value registered. The average $\mathrm{Zn}$ concentration in soils was of $218.2 \mathrm{mg} \mathrm{kg}^{-1}$ but it could reach $713.7 \mathrm{mg} \mathrm{kg}^{-1}$, a level that can be extremely toxic for plants. Cobalt and chromium concentrations in soils were normally low, ranging from 20.1 to $54.3 \mathrm{mg} \mathrm{kg}^{-1}$ for Co and 5.1 to $84.6 \mathrm{mg} \mathrm{kg}^{-1}$ for Cr. Nickel and Ag were also low, varying from 27.2-52.9 to $2.5-16.6$, respectively.

Sampling in the São Domingos area resulted in the collection of 24 plant species. They represent 16 genera and 13 families. Analysis of metals performed in plant material (leaves, twigs, above-ground parts or needles) indicated that different plant parts had different budgets of metals (Table 2). Lead concentration in plants was rather high for some species, varying from 2.9 to $84.9 \mathrm{mg} \mathrm{kg}^{-1}$ dry weight (DW) (Fig. 3). The maximum $\mathrm{Pb}$ content was observed in the aerial parts of Juncus efusus. Semi-aquatic species sampled in the mining area, Juncus conglomeratus and Scirpus holoschoenus, showed high accumulation of lead in plant tissues. Lead above $20 \mathrm{mg} \mathrm{kg}^{-1} \mathrm{DW}$ was found in leaves of three species of Cistus, typical mediterranean shrubs known for their tolerance to drought and low nutrients availability. Arsenic concentration in plant tissues ranged from 0.3 to $23.5 \mathrm{mg} \mathrm{kg}^{-1} \mathrm{DW}$ (Table 2). Maximum arsenic was recorded in J. conglomeratus, Thymus mastichina, J. efusus and S. holoschoenus (Fig. 4). Arsenic and lead are among the most toxic metals found in these soils and the same assemblage of plants seem to better tolerate them (Porter and Peterson, 1975; De Koe and Jaques, 1993; De Koe, 1994; Garcia-Sanchez et al., 1996; Bech et al., 1997; Jonnalagadda and Nenzou, 1997; Ma et al., 2001). Semi-aquatic species from the Juncaceae family showed the highest content of both metals (Table 2, Figs. 3 and 4). A few trees, Eucalyptus, Quercus and Pinus species, were found in the contaminated area showing accumulation of different metals in the aboveground tissues. Due to their high biomass, they can be very effective for metals phytoextraction and phytostabilization especially when established in the less contaminated soils on the peripheral zone of the study area.

Trees, shrubs, grasses, legumes and semi-aquatic plants were represented in the São Domingos mining area contaminated with metallic substrates. Phytoremediation of mining sites is well-established using species of hyperaccumulators and a variety of management practices (Yang et al., 1997; Shu et al., 2000; Zhang et al., 2001; Wong, 2003). Often, a combination of metals and other stress factors such as drought, poor nutrient status and high light intensity occurs at mines or smelting areas. Therefore, mine restoration could benefit from a broader perspective including different groups of plant species as they could perform distinct functional roles in the remediation process. For example, the use of legumes may enrich the soil nutrients content and the combined used of perennials and annuals can provide substantial inputs in terms of organic matter and nutrients recycling, thus contributing in distinct ways to the development of the soil (Hooper and Vitousek, 1997, 1998). This type of approach requires more information about plant communities growing on metal-contaminated soils in order to accurately determine their potential for remediation of polluted soils in abandoned mines.

Mine-degraded soils are man-made habitat which experience a wide range of problems for establishing and maintaining vegetation, depending on the type of mine such as metal mines, coal mines and quarries. The physicochemical properties of the metal-contaminated soils tend to inhibit soil-forming processes and plant growth. In addition to elevated metal concentrations, other adverse factors include absence of topsoil, periodic sheet erosion, drought, surface mobility, compaction, wide temperature fluctuations, absence of soil-forming fine materials, and shortage of essential nutrients (Wong et al., 1999a,b). The original soil of mine-degraded lands is usually lost or damaged, with only skeletal materials. There is commonly a lack of organic matter and its associated nutrients such as nitrogen $(\mathrm{N})$ in most degraded land materials. The minedegraded soils have low concentrations of important nutrients like $\mathrm{K}, \mathrm{P}$ and $\mathrm{N}$. Organic matter provides a continuous source of nutrients, e.g., it provides most of the $\mathrm{N}$ reserve in soils and comprises typically $5 \% \mathrm{~N}$ which is mineralized at about 2\% per year (Harris et al., 1996).

For soils contaminated by trace metals such as copper $(\mathrm{Cu})$, lead $(\mathrm{Pb})$, nickel $(\mathrm{Ni})$ and zinc $(\mathrm{Zn})$, metal toxicity would restrict the growth of all but the most tolerant plants. Toxic metals can also adversely affect the number, diversity and activity of soil organisms, inhibiting soil organic matter decomposition and $\mathrm{N}$ mineralization processes. However, toxicity is not a simple matter of particular concentrations of substances being toxic to a plant. The chemical form of the potential toxic metal, the presence of other chemicals which may aggravate or ameliorate metal toxicity, the prevailing $\mathrm{pH}$ and nutrient status of the contaminated soil will affect the way plants respond to the toxic metal. Substrate $\mathrm{pH}$ affects plant growth mainly through its effect on the solubility of chemicals, including toxic metals and nutrients. It is commonly recognized that at $\mathrm{pH} 6.5$, nutrient availability to plants is at a maximum and toxicity at a minimum (Harris et al., 1996; Wong, 2003). The bioavailability of trace metals to plants and biota including fauna and microorganisms is controlled by their total concentration in the soil and their chemical forms. As to plants, the bioavailability is governed by the factors that control the activity of soluble metal species in the soil solution that is preferentially taken up (Thornton, 1999). Methods for determining the soluble and thus bioavailable fractions of metals in soils have been extensively studied for the past 20 years. For the soil-plant/microorganisms pathway, these included the use of (a) single chemical extractants of varying concentrations, such as EDTA, DTPA, acetic acid and $0.01 \mathrm{M} \mathrm{CaCl} 2$ (Allen, 
Table 2

Concentration of trace elements in soils and plant species of São Domingos mine (in $\mathrm{mg} \mathrm{kg}^{-1}$ dry weight)

\begin{tabular}{|c|c|c|c|c|c|c|c|c|c|c|c|c|c|}
\hline \multirow[t]{2}{*}{ Family/taxa } & \multirow{2}{*}{$\begin{array}{l}\text { Plant } \\
\text { Part }\end{array}$} & \multicolumn{2}{|l|}{$\mathrm{Ag}$} & \multicolumn{2}{|l|}{ As } & \multicolumn{2}{|l|}{$\mathrm{Cu}$} & \multicolumn{2}{|l|}{$\mathrm{Ni}$} & \multicolumn{2}{|l|}{$\mathrm{Pb}$} & \multicolumn{2}{|l|}{$\mathrm{Zn}$} \\
\hline & & Soil & $\overline{\text { Plant DW }}$ & Soil & $\overline{\text { Plant DW }}$ & Soil & Plant DW & Soil & Plant DW & Soil & Plant DW & Soil & Plant DW \\
\hline \multicolumn{14}{|l|}{ Fagacea } \\
\hline \multirow{2}{*}{$\begin{array}{l}\text { Quercus ilex L. subsp. balota } \\
\text { (Desf.) Samp. }\end{array}$} & $\mathrm{L}$ & 5.4 & 0.1 & 353.2 & 0.9 & 529.6 & 6.0 & 47.2 & 3.0 & 1866.3 & 5.3 & 167.8 & 52.0 \\
\hline & $\mathrm{T}$ & 5.4 & 0.2 & 353.2 & 1.4 & 529.6 & 6.6 & 47.2 & 3.4 & 1866.3 & 9.1 & 167.8 & 40.1 \\
\hline \multicolumn{14}{|l|}{ Cistaceae } \\
\hline \multirow[t]{2}{*}{ Cistus salvifolia $\mathrm{L}$. } & $\mathrm{L}$ & 8.7 & 0.2 & 580.5 & 2.1 & 533.4 & 18.0 & 44.9 & 7.3 & 4765.7 & 10.7 & 158.9 & 226.2 \\
\hline & $\mathrm{T}$ & 8.7 & 0.1 & 580.5 & 0.9 & 533.4 & 11.8 & 44.9 & 3.4 & 4765.7 & 17.9 & 158.9 & 130.4 \\
\hline \multirow[t]{2}{*}{ Cistus crispus L. } & $\mathrm{L}$ & 9.1 & 0.3 & 607.3 & 2.1 & 243.3 & 12.4 & 43.2 & 5.1 & 3128.8 & 28.6 & 167.8 & 137.8 \\
\hline & $\mathrm{T}$ & 7.7 & 0.1 & 468.8 & 1.5 & 209.4 & 5.7 & 45.6 & 2.8 & 2437.5 & 31.3 & 158.6 & 122.7 \\
\hline \multirow[t]{2}{*}{ Cistus monspeliensis L. } & $\mathrm{L}$ & 4.8 & 0.3 & 129.2 & 2.1 & 476.8 & 16.0 & 45.5 & 5.9 & 1009.1 & 20.0 & 248.0 & 343.2 \\
\hline & $\mathrm{T}$ & 4.8 & 0.1 & 129.2 & 1.3 & 476.8 & 5.2 & 45.5 & 3.3 & 1009.1 & 20.7 & 248.0 & 142.3 \\
\hline \multirow[t]{2}{*}{ Cistus ladanifer $\mathrm{L}$. } & $\mathrm{L}$ & 7.3 & 0.1 & 443.6 & 2.1 & 443.7 & 13.4 & 46.1 & 4.6 & 3639.6 & 11.0 & 230.8 & 170.1 \\
\hline & $\mathrm{T}$ & 7.3 & 0.2 & 443.6 & 1.8 & 443.7 & 10.0 & 46.1 & 3.7 & 3639.6 & 21.4 & 230.8 & 80.9 \\
\hline \multicolumn{14}{|l|}{ Fabaceae } \\
\hline Genista hirsuta Vahl & A & 7.0 & 0.1 & 259.1 & 0.6 & 944.8 & 5.4 & 42.4 & 2.2 & 2034.3 & 3.5 & 114.4 & 132.9 \\
\hline Ulex eriocladus C. Vicioso & A & 13.1 & 0.1 & 487.4 & 1.5 & 1039.8 & 8.2 & 31.1 & 2.0 & 3914.4 & 13.2 & 103.8 & 35.8 \\
\hline $\begin{array}{l}\text { Genista polyanthos Willk. } \\
\text { subsp. polyanthos }\end{array}$ & A & 3.4 & 0.2 & 88.5 & 6.2 & 284.9 & 6.0 & 43.0 & 3.1 & 378.5 & 12.9 & 113.9 & 84.0 \\
\hline \multicolumn{14}{|l|}{ Lamiaceae } \\
\hline Lavandula stoechas L. subsp. & $\mathrm{L}$ & 2.5 & 0.1 & 72.3 & 1.2 & 151.2 & 8.5 & 46.6 & 2.7 & 756.9 & 19.5 & 138.8 & 201.7 \\
\hline pedunculata Samp. and Rozeira & $\mathrm{T}$ & 2.5 & 0.4 & 72.3 & 0.5 & 151.2 & 5.5 & 46.6 & 1.2 & 756.9 & 11.9 & 138.8 & 76.9 \\
\hline Thymus mastichina $\mathrm{L}$. & A & 7.0 & 0.3 & 203.4 & 13.6 & 948.1 & 25.5 & 44.0 & 1.5 & 1409.2 & 33.4 & 407.4 & 143.4 \\
\hline Asteraceae & & & & & & & & & & & & & \\
\hline Helichrysum stoechas (L.) Moench. & A & 2.9 & 0.2 & 37.2 & 3.6 & 87.3 & 16.4 & 51.4 & 3.2 & 234.2 & 16.9 & 116.0 & 190.2 \\
\hline Poaceae & & & & & & & & & & & & & \\
\hline Agrostis castellana Boiss. and Reuter & A & 6.4 & 0.1 & 187.3 & 2.1 & 196.3 & 3.6 & 42.4 & 2.1 & 1587.7 & 8.5 & 133.8 & 35.8 \\
\hline Myrtaceae & & & & & & & & & & & & & \\
\hline Eucalyptus camaldulensis Dehnh. & $\mathrm{L}$ & 7.0 & 0.2 & 391.5 & 0.6 & 529.1 & 23.8 & 42.8 & 5.0 & 3303.3 & 3.0 & 201.5 & 80.0 \\
\hline & $\mathrm{T}$ & 7.0 & 0.2 & 391.5 & 0.5 & 529.1 & 22.7 & 42.8 & 2.9 & 3303.3 & 2.9 & 201.5 & 74.5 \\
\hline Eucalyptus globulus Labill. & $\mathrm{L}$ & 8.1 & 0.2 & 479.2 & 0.3 & 228.9 & 14.4 & 43.9 & 7.8 & 2524.9 & 3.7 & 162.8 & 25.5 \\
\hline & $\mathrm{T}$ & 8.1 & 0.1 & 479.2 & 0.4 & 228.9 & 18.2 & 43.9 & 3.8 & 2524.9 & 5.2 & 162.8 & 54.7 \\
\hline Ericaceae & & & & & & & & & & & & & \\
\hline Erica australis L. & A & 16.2 & 0.2 & 989.2 & 1.0 & 1089.8 & 6.7 & 30.7 & 1.5 & 11217.5 & 8.8 & 108.4 & 18.7 \\
\hline Erica erigena R. Ross. & $\mathrm{L}$ & 3.5 & 0.1 & 163.9 & 5.3 & 219.4 & 12.2 & 35.3 & 2.3 & 2272.7 & 28.2 & 167.3 & 23.8 \\
\hline & $\mathrm{T}$ & 3.5 & 0.3 & 163.9 & 3.0 & 219.4 & 14.4 & 35.3 & 1.1 & 2272.7 & 18.3 & 167.3 & 12.2 \\
\hline Polygoneaceae & & & & & & & & & & & & & \\
\hline Rumex induratus Boiss. and Reuter & A & 16.6 & 0.1 & 949.7 & 1.4 & 1113.2 & 21.1 & 33.9 & 1.5 & & 7.8 & 416.4 & 25.9 \\
\hline Pinaceae & & & & & & & & & & & & & \\
\hline Pinus pinaster Aiton & $\mathrm{L}$ & 9.5 & 0.3 & 1291.0 & 0.8 & 365.4 & 4.6 & 49.5 & 4.3 & 5157.9 & 4.3 & 292.8 & 82.4 \\
\hline & $\mathrm{T}$ & 9.5 & 0.2 & 1291.0 & 0.6 & 365.4 & 7.7 & 49.5 & 4.1 & 5157.9 & 3.9 & 292.8 & 58.9 \\
\hline Pinus pinea $\mathrm{L}$. & $\mathrm{N}$ & 9.5 & 0.2 & 1291.0 & 0.6 & 365.4 & 8.9 & 49.5 & 5.5 & 5157.9 & 5.9 & 292.8 & 51.4 \\
\hline Thymelaeaceae & & & & & & & & & & & & & \\
\hline Daphne gnidium L. & $\mathrm{L}$ & 7.0 & 0.1 & 203.4 & 1.2 & 948.1 & 7.1 & 44.0 & 1.7 & 1409.2 & 10.8 & 407.4 & 308.8 \\
\hline & $\mathrm{T}$ & 7.0 & 0.2 & 203.4 & 1.1 & 948.1 & 14.2 & 44.0 & 1.0 & 1409.2 & 8.2 & 407.4 & 102.3 \\
\hline Lentibulariaceae & & & & & & & & & & & & & \\
\hline Pistachia lentiscus L. & $\mathrm{L}$ & 11.5 & 0.3 & 385.7 & 1.1 & 1829.0 & 6.9 & 38.2 & 1.7 & 2713.7 & 9.6 & 713.7 & 28.6 \\
\hline & $\mathrm{T}$ & 11.5 & 0.2 & 385.7 & 0.7 & 1829.0 & 10.1 & 38.2 & 1.2 & 2713.7 & 4.7 & 713.7 & 32.8 \\
\hline Juncaceae & & & & & & & & & & & & & \\
\hline Scirpus holoschoenus L. & A & 4.4 & 0.2 & 204.2 & 8.0 & 203.6 & 21.9 & 27.2 & 1.2 & 3136.4 & 51.7 & 158.1 & 38.3 \\
\hline Juncus conglomeratus L. & A & 4.4 & 0.3 & 204.2 & 23.5 & 203.6 & 28.9 & 27.2 & 1.7 & 3136.4 & 84.8 & 158.1 & 70.7 \\
\hline Juncus efusus L. & A & 4.4 & 0.4 & 204.2 & 8.5 & 203.6 & 18.0 & 27.2 & 1.7 & 3136.4 & 22.4 & 158.1 & 96.1 \\
\hline
\end{tabular}

L: leaves; T: twigs; A: aboveground parts; N: needles. 


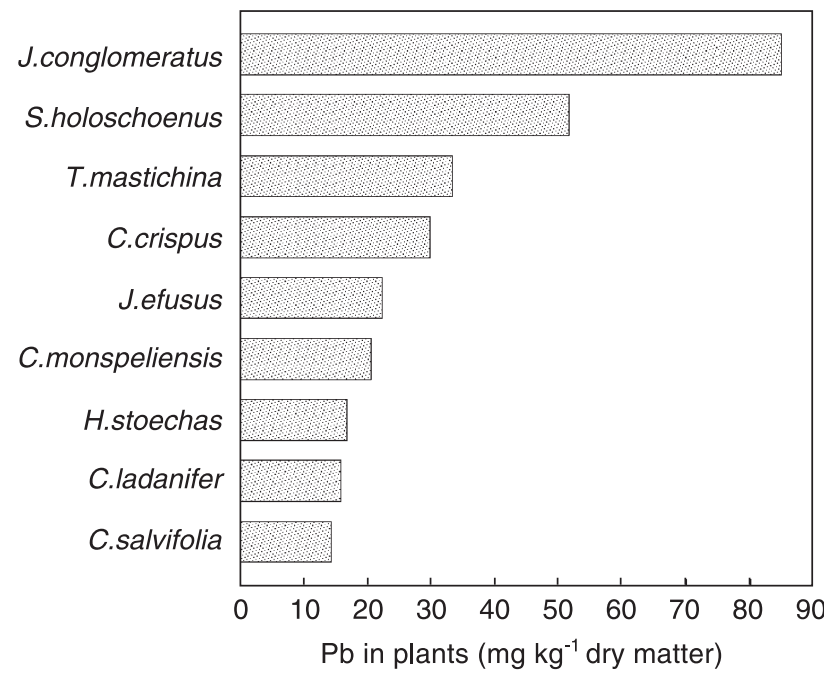

Fig. 3. Accumulation of lead in plant species from the São Domingos mining area.

1989) and (b) operationally defined sequential extraction procedures (Tessier et al., 1979) in which increasing strong extractants are used to release metals associated with different soil fractions.

Selection of appropriate plant species would be very important to ensure a self-sustainable vegetation cover (Wong, 2003). Phytoremediation refers to the use of green plants and their associated microbiota, soil amendments, and agronomic techniques to remove, contain, or render harmless environmental contaminants (Cunningham and Ow, 1996; Prasad and Freitas, 1999, 2003). Phytoremediation of heavy metal-contaminated soils basically includes phytostabilization and phytoextraction.

Some soils are so heavily contaminated that removal of metals using plants would take an unrealistic amount of time. The normal practice is to choose drought resistant, fast-growing crops or fodder, which can grow in metalcontaminated and nutrient-deficient soils. Phytostabilization is the use of metal-tolerant plant species to immobilize trace metals through absorption and accumulation by roots, adsorption onto roots, or precipitation within the rhizosphere. This process reduces metal mobility and also reduces bioavailability for entry into the food chain. By using metal-tolerant plant species for stabilizing mine spoils, it could also provide improved conditions for natural attenuation. Some plant cultivars tolerant to toxic metals are available commercially in some countries such as the UK and Australia (Lothenbach et al., 1998). The existence of these plant varieties is the result of evolution rather than innate physiological tolerance (Bradshaw, 1993). These included single (Cynodon dactylon) and multiple (Festuca rubra, Typha latifolia and Phragmites australis) (Wong, 2003; Ye et al., 1997) tolerances to trace metals. There is literally growing evidence that phytostabilization can be achieved by selective planting in combination with a various soil amendments such as zeolites, beringite, steel shot and hydroxyapatite that immobilize metals in soil (Lothenbach et al., 1998).

Successful establishment and colonization of several pioneer plant species tolerant to $\mathrm{Pb} / \mathrm{Zn}$ mine spoils has been demonstrated. The tolerant plants included grasses viz., Vetiveria zizanioides, (Shu et al., 2000), shrubby legume Sesbania rostrata, (Yang et al., 1997), and woody legume Leucaena leucocephala (Zhang et al., 2001). Therefore, selection of appropriate plant species which can establish, grow and colonize metal-contaminated soils is important for successful reclamation of degraded mine sites (Wong, 2003). Vetiver grass ( $V$. zizanioides) has a massive finely structured and deep root system capable of reaching 3-4 m in the first year. Due to its unique morphological and physiological characteristics, it has been commonly known for its effectiveness in erosion and sediment control, and has also been found to be highly tolerant to extreme soil conditions including prolonged drought, flood, submergence, extreme temperature $\left(10\right.$ to $\left.48{ }^{\circ} \mathrm{C}\right)$, and a wide range of soil acidity and alkalinity ( $\mathrm{pH}$ from 3 to 10.5). The plant is also highly tolerant to soil salinity, sodicity, acidity, Al, $\mathrm{Mn}$ and heavy metal (such as $\mathrm{As}, \mathrm{Cd}, \mathrm{Cr}, \mathrm{Ni}, \mathrm{Pb}, \mathrm{Zn}, \mathrm{Hg}$, Se and $\mathrm{Cu}$ ) toxicities in the soil (Wong, 2003).

Greenhouse and field trials in Queensland, Australia have shown that vetiver grass is suitable for the rehabilitation of metal-contaminated soils, and for the treatment of landfill leachate (Truong and Baker, 1988). Recently, it has been found that vetiver grass was the best plant species (in terms of biomass production and coverage) when compared with other three grass species, namely Paspalum notatum, C. dactylon and Imperata cyclindrica var. major used for revegetating $\mathrm{Pb} / \mathrm{Zn}$ mine tailings in South China (Shu et al., 2000). In addition, oil products extracted from vetiver roots pose high values in biomedical utilization. By planting vetiver grass in metal-contaminated soils, it will fulfil the dual purpose of stabilizing the site and modifying soil

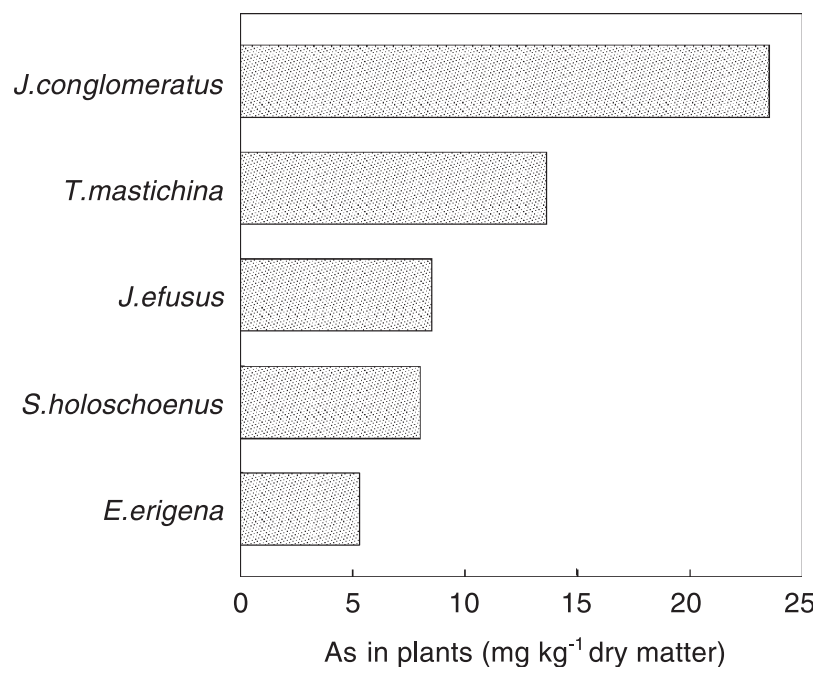

Fig. 4. Accumulation of arsenic in plant species of the São Domingos mining area. 
properties suitable for the colonization of other plants, and at the same time producing oils with a high commercial value. It is essential to investigate if there were higher metal concentrations taken up by the grass, and the subsequent effects on the quantity and quality of the oil products. An annual legume native to Africa $S$. rostrata which possesses stem as well as root nodules can be used to modify properties of mine spoils, by supplying the much needed $\mathrm{N}$ and organic matter. The plant is able to complete its life cycle and produce seeds within 4 months after growing on bare $\mathrm{Pb} / \mathrm{Zn}$ mine tailings. Apart from having a very high growth rate, it is also tolerant to toxic metals and low nutrient status, and therefore will be an ideal pioneer species to accelerate ecological succession of the man-made habitats (Bradshaw, 1993).

\section{Conclusions}

In order to achieve a self-sustainable vegetation on toxicmetal-mined lands, it is essential to choose plant materials which are tolerant to the specific metals, as well as tolerant to drought and the lack of nutrients. Adding organic amendment is essential to facilitate the establishment and colonization of these "pioneer plants". They can eventually modify the man-made habitat and render it more suitable for subsequent plant communities. Planting of different grass species, rotating with legumes and native species will be able to restore soil fertility and accelerate ecological succession. The use of hyperaccumulator plants seems to be only effective for cleaning up soils containing light to moderate toxic metal concentration.

\section{References}

Allen SE. Chemical analysis of ecological materials. 2nd ed. Oxford: Blackwell; 1989.

Aslin GEM. The determination of arsenic and antimony in geological materials by flameless atomic absorption spectrometry. J Geochem Explor 1976;6:321-30.

Badri M, Springuel I. Biogeochemical prospecting in the south-eastern desert of Egypt. J Arid Environ 1994;28:257-64.

Baker AJM. Accumulators and excluders: strategies in the response of plants to trace metals. J Plant Nutr 1981;3:643-54.

Baker AJM. Metal hyperaccumulation by plants: our present knowledge of the ecophysiological phenomenon. Will plants have a role in bioremediation? 14th Annual symposium on current topics in plant biochemistry, physiology and molecular biology, Columbia, MO; 1995. p. 7-8.

Baker AJM, Reeves RD, McGrath SP. In situ decontamination of heavy metal polluted soils using crops of metal-accumulating plants - a feasibility study. In: Hinchee RE, Olfenbuttel RF, editors. In situ bioreclamation. Boston: Butterworth-Heinemann; 1991. p. 600-5.

Baker AJM, McGrath SP, Sidoli CMD, Reeves RD. The possibility of in situ heavy metal decontamination of polluted soils using crops of metalaccumulating plants. Resour Conserv Recycl 1994;11:41-9.

Banuelos GS, Ajwa HA. Trace elements in soils and plants: an overview. J Environ Sci Health, Part A 1999;34(4):951-74.

Bech J, Poschenrieder C, Llugany M, Barceló J, Tume P, Tobias FJ, et al.
Arsenic and heavy metal contamination of soil and vegetation around a copper mine in Northern Peru. Sci Total Environ 1997;203:83-91.

Bradshaw AD. Understanding the fundamentals of succession. In: Miles J, Walton DH, editors. Primary succession on land. Oxford: Blackwell; 1993.

Brooks RR. Biological methods of prospecting for minerals. New York: Wiley-Interscience; 1983. p. 313

Brooks RR. Plants that hyperaccumulate trace metals. UK: Wallingford CAB International; 1998. p. 380

Brooks RR, Lee J, Reeves RD, Jaffrè T. Detection of nickeliferous rocks by analysis of herbarium specimens of indicator plants. J Geochem Explor 1977;7:49-57.

Castroviejo S, Lainz M, Lopez Gonzalez G, Monserrat P, Munoz Garmendia F, Paiva J, Villar L, editors. Lycopodiaceae-Papaeraceae. Flora Iberica. Plantas Vasculares de la Peninsula Iberica e Islas Baleares, vol. I. CSIC, Madrid: Real Jardin Botanico; 1986. p. 575.

Castroviejo S, Lainz M, Lopez Gonzalez G, Monserrat P, Munoz Garmendia F, Paiva J, Villar L, editors. Platanaceae-Plumbaginaceae (partim). Flora Iberica. Plantas Vasculares de la Peninsula Iberica e Islas Baleares, vol. II. CSIC, Madrid: Real Jardin Botanico; 1990. p. 897.

Castroviejo S, Aedo C, Cirujano S, Lainz M, Monserrat P, Morales R, Munoz Garmendia F, Navarro C, Paiva J, Soriano C, editors. Plumbaginaceae (partim) Capparaceae. Flora Iberica. Plantas Vasculares de la Peninsula Iberica e Islas Baleares, vol. III. CSIC, Madrid: Real Jardin Botanico; 1993. p. 730.

Castroviejo S, Aedo C, Benedi C, Lainz M, Munoz Garmendia F, Nieto Feliner G, Paiva J, editors. Haloragaceae-Euphorbiaceae. Flora Iberica. Plantas Vasculares de la Peninsula Iberica e Islas Baleares, vol. VIII. CSIC, Madrid: Real Jardin Botanico; 1997. p. 375.

Chaney RL. Plant uptake of inorganic waste constitutes. In: Parr JK, Marsh PB, Kla JM, editors. Land treatment of hazardous wastes. Park Ridge, IL: Noyes Data; 1983. p. 50-76.

Commission of the European Communities. Council Directive of 12 June 1986 on the protection of the environment, and in particular of the soil, when sewage sludge is used in agriculture. Off $\mathrm{J}$ Eur Communities 1986;L181(86/2781EEC):6-12.

Cunningham SD, Ow DW. Promises and prospects of phytoremediation update on biotechnology. Plant Physiol 1996;110:715-9.

De Koe T. Agrostis castellana and Agrostis deliculata on heavy metal and arsenic enriched sites in NE Portugal. Sci Total Environ 1994;145: $103-9$.

De Koe T, Jaques NMM. Arsenate tolerance in Agrostis castellana and Agrostis deticulata. Plant Soil 1993;151:185-91.

Fletcher WK. Analytical methods in geochemical prospecting. In: Govett GJS, editor. Handbook of exploration geochemistry, vol. 1. Amsterdam: Elsevier; 1981. 255 pp.

Franco JA. Nova Flora de Portugal (Continente e Açores). Lisboa: Escolar Editora; 1971.

Garcia-Sanchez A, Santa Regina I, Jimenez O. Arsenic environmental impact on mining areas (Salamanca, Spain). Toxicol Environ Chem 1996;53:137-41.

Gaspar O. História da mineração dos depósitos de sulfuretos maciços vulcanogénicos da faixa piritosa portuguesa. Bol Minas 1998;35(4) [Lisboa].

Hadjiliads ND, editor. Cytotoxicity, mutagenic and carcinogenic potential of heavy metals related to human environment. NATO-ASI series 2. Environment, vol. 26. Dordrecht: Kluwer Academic Publishing; 1997. p. 629

Harris JA, Birch P, Palmer JP. Land restoration and reclamation. Principles and practice. London: Longman; 1996.

Hesse PR. A text book of soil chemical analysis. London: Jonh Murray Publishers; 1971. p. 520.

Hooper DU, Vitousek PM. The effects of plant composition and diversity on ecosystem processes. Science 1997;277:1302-5.

Hooper DU, Vitousek PM. Effect of plant composition and diversity on nutrient cycling. Ecol Monogr 1998;68:121-49.

Jonnalagadda SB, Nenzou G. Studies on arsenic rich mine dumps: II. The 
heavy element uptake by vegetation. J Environ Sci Health Part A 1997;32(2):455-64.

Kabata-Pendias A. Trace elements in soil and plants. Florida: CRC Press, 2001. p. 432.

Kovalevskii AL. Biogeochemical exploration for mineral deposits. Nova Deli: Oxonian Press PVT; 1979. 136 pp.

Lothenbach B, Krebs R, Furrer G, Gupta SK, Schulin R. Immobilization of cadmium and zinc in soil by Al-montmorillonite and gravel sludge. Eur J Soil Sci 1998;49:141-8.

Lucas MD, Sequeira EM. Determinações de alumínio, cálcio, cobalto, cobre, ferro, magnésio, manganésio, potássio, sódio, titânio e zinco to tais nos solos por ataque nítrico-perclórico-fluorídrico e por absorção atómica e emissão de chama, pedologia. Oeiras 1971;6:55-66.

Ma LQ, Komar KM, Tu C, Zhang W, Cai Y, Kennelley ED. A fern that hyperaccumulates arsenic. Nature 2001;409:579.

McGrath SP, Sidoli CMD, Baker AJM, Reeves RD. The potential for the use of metal-accumulating plants for the in situ decontamination of metal polluted soils. In: Eijasackers HJP, Hamers T, editors. Integrated soil and sediment research: a basis for proper protection. Dordrecht, The Netherlands: Kluwer Academic Publishing; 1993. p. 673-6.

McInnes BIA, Dunn C, Cameron EM, Kameko L. Biogeochemical exploration for gold in tropical rain forest regions of Papua New Guinea. J Geochem Explor 1996;57:227-43.

Nriagu JO. Global inventory of natural and anthropogenic emissions of trace metals to the atmosphere. Nature 1979;279:409-11.

Porter EK, Peterson PJ. Arsenic accumulation by plants on mine waste. Sci Total Environ 1975;4:365-71.

Prasad MNV, Freitas H. Feasible biotechnological and bioremediation strategies for serpentine soils and mine soils. Electron J Biotechnol 1999;2:36-50 (Online journal). [http://www.ejbiotechnology.info/ content/vol2/issue1/full/5/ 26 Nov 2002].

Prasad MNV, Freitas H. Metal hyperaccumulation in plants-biodiversity prospecting for phytoremediation technology. Electron J Biotechnol (Online journal) 2003. [http://www.ejbiotechnology.info].

Pratas JAMS. Aplicações de prospecção biogeoquímica. selecção de espécies bioindicadoras em algumas áreas mineiras de portugal. $\mathrm{PhD}$ thesis, vol. 3. Universidade de Coimbra; 1996. p. 1027.

Raskin I, Ensley ED. Phytoremediation of toxic metals using plants to clean up the environment. John Wiley \& Sons Inc; 2000. p. 304.

Ross SM, editor. Toxic metals in soil and plant systems. Chichester, UK: Wiley; 1994.

Sengupta M. Environmental impacts of mining: monitoring, restoration and control. Boca Raton, FL: Lewis; 1993.

Shaw AJ. Heavy metal tolerance in plants: evolutionary aspects. Boca Raton, FL: CRC Press; 1990.
Shu WS, Lan CY, Zhang ZQ, Wong MH. Use of vetiver and other three grasses for revegetation of $\mathrm{Pb} / \mathrm{Zn}$ mine tailings at Lechang, Guangdong Province: field experiment. 2nd Int. vetiver conf., Bangkok, Thailand; 2000.

Soil Survey Staff. Keys to soil taxonomy. 7th ed. Blacksburg, VA: Pocahontas Press; 1997. p. 545.

Talavera S, Aedo C, Catroviejo S, Romero Zarco C, Saez L, Salgueiro FJ, Velayos M, editors, Leguminosae (Partim). Flora Iberica. Plantas Vasculares de la Penýnsula Ibérica e Islas Baleares, vol. VII. Botanico, CSIC, Madrid: Real Jardin; 1999.

Tessier A, Campbell PGC, Bisson M. Sequential extraction procedure for the speciation of particulate trace metals. Anal Chem 1979;52:844-51.

Thornton L. Bioavailability of trace metals in the food chain. 2nd Int. Vetiver Conf., Bangkok, Thailand; 1999.

Truong PN, Baker D. Vetiver grass system for environmental protection. Technol. Bull., vol. 1988/1. Bangkok, Thailand: Pacific Rim Vetiver Network. Office of the Royal Development Projects Board; 1988.

Van Loon JC. Selected methods of trace metal analysis: biological and environmental samples. London: Wiley; 1985. 355 pp.

Vijan PN, Rayner AC, Sturgis D, Wood GR. A semi-automated method for the determination of arsenic in soil and vegetation by gas-phase sampling and atomic absorption spectrometry. Anal Chim Acta 1976;82: $329-36$.

Wenzel WW, Lombi E, Adriano DC. Biogeochemical processes in the rhizosphere: role in phytoremediation of metal-polluted soils. In: Prasad MNV, Hagemeyer J, editors. Heavy metal stress in plants-from molecules to ecosystems. Berlin: Springer-Verlag; 1999. p. 271-303.

Wong JWC, Chen Q, Zhang FS, Wong MH, Baker AJM. Phytostabilization of mimicked cadmium contaminated soil with lime amendment. Proc. 5th Int. Conf. Biogeochem. Trace Elements, Vienna; 1999a. p. 898-9.

Wong MH, Lan CY, Gao L, Chen HM. Current approaches to managing and remediating metal contaminated soils in China. Proc. 5th Int. Conf. Biogeochem. Trace Elements, Vienna, Austria; 1999b; p. 232-3.

Wong MH. Ecological restoration of mine degraded soils, with emphasis on metal contaminated soils. Chemosphere 2003;50:775-80.

Yang ZY, Yuan JG, Xin GR, Chang HT, Wong MH. Germination, growth and nodulation of Sesbania rostrata grown in $\mathrm{Pb} / \mathrm{Zn}$ mine tailings. Environ Manage 1997;21:617-22.

Ye ZH, Baker AJM, Wong MH, Willis AJ. Zinc, lead and cadmium tolerance, uptake and accumulation by Typha latifolia. New Phytol 1997; 136:469-80.

Zhang ZQ, Shu WS, Lan CY, Wong MH. Soil seed bank as an input of seed source in revegetation of lead/zinc mine tailings. Restor Ecol 2001;9: 1-8. 